The Bangladesh Veterinarian (2012) 29(1) : 31 - 37

\title{
Responses of monosex nile tilapia (Oreochromis niloticus) to intraperitoneal challenge by Streptococcus iniae after vaccination with ghosts of the bacterium
}

\author{
M. M. M. Hossain*, A. Ehsan¹, M. A. Rahman, M. B. R. Chowdhury² and M. Haq \\ Department of Fisheries and Marine Bioscience, Jessore Science and Technology \\ University, Jessore-7408, Bangladesh
}

\begin{abstract}
The vaccine potential of Streptococcus iniae ghosts produced by gene E mediated lysis was investigated using tilapia (Oreochromis niloticus). Tilapia immunized with $S$. iniae ghosts (SIG) and formalin killed S. iniae (FKC) vaccines showed significantly higher serum agglutination titres than control fish. Fish immunized with SIG showed no significant differences with fish immunized with FKC in serum agglutination titres, but showed significantly higher bactericidal activity than fish immunized with FKC. Furthermore, fish immunized with SIG showed higher protection than fish immunized with FKC. As this promising type of a non-living whole cell envelope preparation seems to be favorable over conventional vaccines, we suggest $S$. iniae ghosts as a new vaccine candidate. (Bangl. vet. 2012. Vol. 29, No. 1, 31 - 37)
\end{abstract}

\section{Introduction}

S. iniae is a Gram-positive, oxidase-negative, catalase-negative, sphere-shaped bacterium. It is the main etiological agent of streptococcosis also caused by Streptococcus and Lactococcus spp., in a variety of fresh and saltwater fish species in worldwide and results in estimated losses $\$ 150$ million in annually (Shoemaker and Klesius, 1997). Because, antibiotic resistance of $S$. iniae has been reported widely in the world (Park et al., 2009), there is urgent need to find other approaches for the treatment and prevention of this infection. Over the last decade vaccination has become important for the prevention of infectious diseases in farmed fish (Gudding et al., 1999). Although, several attempts have been made to induce protection against S. iniae (Eldar et al., 1997; Kvitt and Colorni, 2004) and the protection efficiency was variable among the studies. Recently, the outer membrane proteins of pathogenic bacteria have been studied in relation to inducing protective humoral and cellmediated immunity (Heckels et al., 1989; Kawai et al., 2004). However, traditional inactivation of bacteria by heat or formalin may influence the physico-chemical

\footnotetext{
1 South-West Area Integrated Water Resources Planning and Management Project, Bangladesh Water Development Board, Jessore, Bangladesh

2 Department of Aquaculture, Faculty of Fisheries, Bangladesh Agricultural University, Mymensingh, Bangladesh

${ }^{*}$ Corresponding author:- E-mail: mmiron_bau@yahoo.com
} 
characteristics of surface antigens, and immune responses against the modified antigens may not be protective against live bacteria. The genetic inactivation of pathogenic Gram-positive bacteria by the controlled expression of cloned bacteriophage Phi X 174 lysis gene E offers a promising new approach in non-living vaccine technology (Eko et al., 1996; Szostak et al., 1996). Expression of plasmidencoded gene $\mathrm{E}$ leads to the formation of a transmembrane tunnel structure through the cell envelope of Gram-positive bacteria, which consequently leads to the loss of cytoplasmic contents. The resultant ghosts have been known to retain the functional and antigenic determinants of the envelope with their living counterparts and thus represent ideal vaccine candidates (Witte et al., 1992). In the present study, we investigated the vaccine potential of $S$. iniae ghosts in monosex nile tilapia.

\section{Materials and Methods}

Fish

Juvenile tilapia, weighing $95 \pm 20 \mathrm{~g}$ was obtained from the fish farm in SouthWest Area Integrated Water Resources Planning and Management Project (SAIWRPMP) funded by Asian Development Bank (ADB), Ministry of Water Resource and Bangladesh Water Development Board (BWDB), Bangladesh. For the immunization experiments, fish were stocked into either three 150 litre aquaria at a density of 30 fish per aquarium, or a single 100 litre aquarium at a density of 100 fish. Fish were acclimated for two weeks prior to initiating the experiments.

\section{Bacterial strain}

Streptococcus iniae SI01 provided by SAIWRPMP, was grown in Brain heart infusion (BHI) medium (broth and agar) at $27^{\circ} \mathrm{C}$. Transformed S. iniae was grown in BHI containing $50 \mathrm{mg} / \mathrm{mL}$ ampicillin (Sigma Chemical Co., St Louis, MO, USA). Incubation temperatures for repression and expression of lysis gene $\mathrm{E}$ in transformants were $27^{\circ} \mathrm{C}$ and $42^{\circ} \mathrm{C}$, respectively. Growth and lysis of bacterial cultures were monitored by measuring the optical density at $600 \mathrm{~nm}\left(\mathrm{OD}_{600}\right)$.

Production of S. iniae ghosts (SIG)

Lyophilized S. iniae ghosts were produced as described previously (Kwon et al., 2005). Briefly, S. iniae harboring the lysis plasmid p $\lambda$ PR-cI-Elysis was induced for lysis after growth under culture conditions by elevation of temperature from $27^{\circ} \mathrm{C}$ and $42^{\circ} \mathrm{C}$. At the end of lysis, ghosts were harvested, washed and resuspended in phosphate buffered saline (PBS) and then lyophilized. The efficiency of E-mediated killing of $S$. iniae was estimated by plating samples of appropriate dilutions of lyophilized SIG on BHI agar containing $50 \mathrm{mg} / \mathrm{mL}$ ampicillin and results were compared with those from samples obtained prior to onset of lysis. Results indicated a $100 \%$ killing efficiency as no colony-forming units were found on plates with lyophilized SIG preparations at any dilution. 


\section{Production of formalin-killed S. iniae (FKC)}

S. iniae was grown for $24 \mathrm{~h}$ at $27^{\circ} \mathrm{C}$ in tryptic soy broth (TSB, Sigma, USA) containing $1.5 \% \mathrm{NaCl}$. For FKC preparation, formalin was added to a $24 \mathrm{~h}$ culture of the bacterium to make the final concentration $0.5 \%$. After $24 \mathrm{~h}$ incubation, cells were washed three times with PBS (pH 7.2) and resuspened in $10 \mathrm{~mL}$ PBS. The suspensions were streaked on tryptic soy agar containing $1.5 \% \mathrm{NaCl}$ for checking sterility and stored at $4^{\circ} \mathrm{C}$ until use.

\section{Immunization and collection of blood samples}

SIG and FKC preparations were reconstituted with PBS. In vaccine experiment I, groups of fish (25 fish/group) stocked into three aquaria were immunized twice intraperitoneally (ip), two weeks apart, with $1.4 \times 10^{6}$ cells of either SIG or FKC in $50 \mathrm{~mL}$ of PBS. A group that received PBS $(50 \mathrm{~mL})$ ip represented the control. Two weeks after the last vaccine dose (day 28), 10 fish in each group were randomly sampled and blood specimens were collected from the caudal vein for agglutination and bactericidal tests. In vaccine experiment II, fish stocked into a single aquarium were randomly divided into three groups ( 25 fish/group) by pectoral fin clipping and were cohabitated in a single aquarium to eliminate tank effects. The immunization regime of experiment II was the same as that of experiment I.

\section{Agglutination activity of serum}

The agglutination test was conducted in ' $U$ '-shaped microtitre plates. The antisera raised in fish and test sera were serially diluted two-fold, to which a constant amount of FKC (approximately $4 \mathrm{mg} / \mathrm{mL}$ ) were added and kept overnight at room temperature. The agglutination activity was determined as the first serum dilution where no agglutination occurred, and expressed as the reciprocal of that dilution.

\section{Bactericidal activity of serum}

The serum bactericidal activity was determined according to Yin et al. (1996) with some modifications. The bacterial cultures were pelleted $(3000 \mathrm{~g}, 10 \mathrm{~min})$ and washed three times with sterile PBS. The bacterial suspension was adjusted to $4 \times 10^{9}$ cells/mL. A volume of $25 \mu \mathrm{L}$ bacterial suspension and $25 \mu \mathrm{L}$ serum of fish in each group were mixed in sterile Eppendorf tubes. They were incubated at room temperature for $1 \mathrm{~h}$, and subsequently, were used to determine colony forming units $(\mathrm{CFU}) / \mathrm{mL}$ by plating the mixtures on TSA containing $1.5 \% \mathrm{NaCl}$.

\section{Challenge test}

To enhance the virulence, $S$. iniae had been passaged in naive tilapia by intraperitoneal injection. The bacterium was reisolated from the kidney of moribund fish three day later and cultured on TSA plates supplemented with $1.5 \% \mathrm{NaCl}$ for $24 \mathrm{~h}$ at $27^{\circ} \mathrm{C}$. The bacterial cell suspension was adjusted to $5 \times 10^{7}$ cells $/ \mathrm{mL}$. Fish (20 fish/group in experiment I and 25 fish/group in experiment II) were challenged by $100 \mathrm{~mL}\left(5 \times 10^{6}\right.$ cells $/ \mathrm{mL}$ cells/fish $)$ of the bacterial suspension ip two weeks after 
the booster dose. Deaths were recorded over 25 days. Dead fish were collected daily and necropsied and kidney samples were streaked on Salmonella Shigella agar (SS agar, Difco) to confirm the presence of S. iniae.

\section{Statistical analysis}

Serum agglutination and bactericidal data were analyzed by the Student's t-test, and challenge test data were analyzed by the Chi-square test. Significant differences were determined at $\mathrm{P}<0.05$.

\section{Results and Discussion}

Agglutination and bactericidal activities of serum

Fish immunized with SIG or FKC showed significantly higher agglutination titre than control fish (Fig. 1). Although, fish immunized with SIG showed higher agglutination titre than fish immunized with FKC, there were no significant differences between these two groups of fish. In serum bactericidal activity, fish immunized with SIG showed significantly higher activity than fish immunized with FKC (Fig. 2). The fish in the control group showed the lowest serum bactericidal activity.

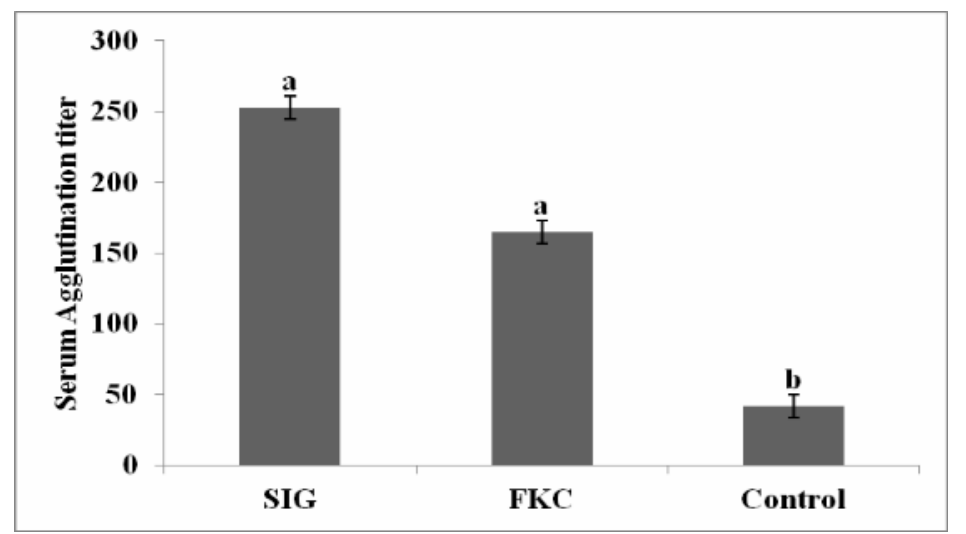

Fig. 1. Serum agglutination titre of tilapia immunized intraperitoneally with Streptococcus iniae ghosts (SIG), and formalin-killed S. iniae (FKC) or PBS alone (Control) after two weeks of the boost immunization. Values are mean \pm standard error. Different letters on the bar indicate statistically significant differences at $\mathrm{P}<0.05$

\section{Protective efficacy of SIG vaccine}

In vaccine experiment I, groups of fish immunized with SIG and FKC showed significantly higher survival rate than control fish (Fig. 3). Furthermore, fish vaccinated with SIG showed significantly higher survival rate than fish vaccinated with FKC. In vaccine experiment II, the cumulative mortalities of control, FKC and SIG immunized groups were $20 \%, 8 \%$ and $0 \%$, respectively. All dead fish were positive for S. iniae. 
Our new approach to produce a non-living Streptococcus iniae ghosts vaccine is based on the gene E-mediated lysis of cells, which has been extensively investigated in E. coli (Witte and Lubitz, 1989; Witte et al., 1992; Schön et al., 1995; Witte et al., 1997). Lysis of bacteria by controlled expression of gene E leading to empty cell envelopes is suggested as an alternative method for inactivation of bacteria without chemical or physical stress, which can reduce antigenicity. The potential usefulness of this technology has recently been reported in mammalian pathogenic Gram-negative and positive bacteria (Eko et al., 1994; Eldar et al., 1997; Katinger et al., 1999; Panthel et al., 2002; Marchart et al., 2003; Kvitt and Colorni, 2004). In the present study, we have tested the degree of protection and immune response induced after immunization of tilapia with S. iniae ghosts vaccine.

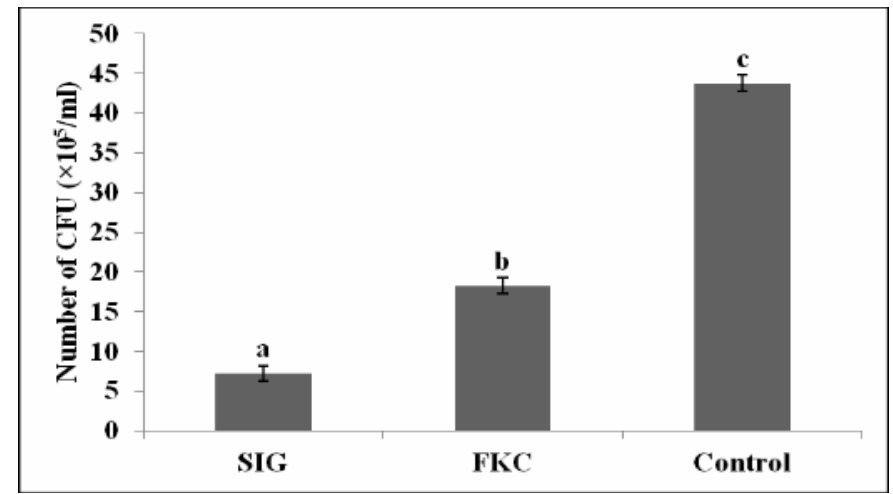

Fig. 2. Serum bactericidal activity of tilapia immunized intraperitoneally with Streptococcus iniae ghosts (SIG), and formalin-killed S. iniae (FKC) or PBS alone (Control) after two weeks of the boost immunization. The bactericidal activity of the serum was expressed as the number of colony forming unit (CFU)/mL of $S$. iniae after $1 \mathrm{~h}$ incubation with each serum. Values are mean \pm standard error. Different letters on the bar indicate statistically significant differences at $\mathrm{P}<0.05$

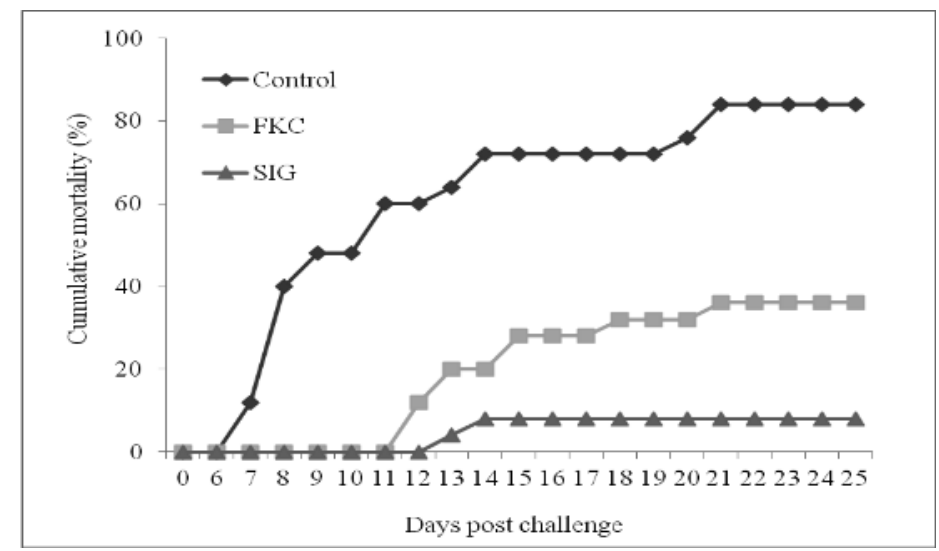

Fig. 3. Cumulative mortality of tilapia immunized intraperitoneally with Streptococcus iniae ghosts (SIG), and formalin-killed S. iniae (FKC) or PBS alone (Control) after challenge with Streptococcus iniae 
In the present study, significantly higher serum agglutination titres in SIG or FKC immunized fish than control fish indicate, that both SIG and FKC induced specific humoral immunity in tilapia. Fish immunized with SIG showed significantly higher serum bactericidal activity and higher survival rates than FKC immunized fish. These results suggest that SIG has higher potential to induce protective antibodies than FKC. Compared to heat or formalin killed bacterial vaccines, the adjuvant effect of ghost bacterial vaccines has been reported in mammalian pathogenic bacteria (Jalava et al., 2002). Moreover, there are some reports, which show effective induction of cellmediated immunity, which would play a key role in protection against intracellular pathogens by S. iniae ghost's vaccine (Eldar et al., 1997; Haslberger et al., 1997; Haslberger et al., 2000).

As this promising type of a non-living whole cell envelope preparation seems to be favorable over conventional vaccines, we suggest $S$. iniae ghosts as a new vaccine candidate.

\section{Acknowledgements}

This study was supported by a grant from the South-West Area Integrated Water Resources Planning and Management Project funded by Asian Development Bank, Ministry of Water Resource and Bangladesh Water Development Board, Bangladesh.

\section{References}

Eko FO, Szostak MP, Wanner G, Lubitz W 1994: Production of Vibrio cholera-ghosts (VCG) by expression of a cloned phage lysis gene: potential for vaccine development. Vaccine 12 1231-1237.

Eko FO, Witte A, Huter V, Kuen B, Fu“rst-Ladani S 1996: New strategies for combination vaccines based on the extended recombinant bacterial ghost system. Vaccine 17 1643-1649.

Gudding R, Lillehaug A, Evensen O 1999: Recent developments in fish vaccinology. Veterinary Immunology and Immunopathology 72 203-212.

Haslberger A, Mader HJ, Schmalnauer M, Kohl G, Messner P, Sleytr UB 1997: Bacterial cell envelopes (ghosts) and LPS but not bacterial S-layers induce synthesis of immunemediators in mouse macrophages involving CD14. Journal of Endotoxin Research 4 431-441.

Haslberger AG, Kohl G, Felnerova D, Mayr UB, Fu“rst-Ladani S, Lubitz W 2000: Activation stimulation and uptake of bacterial ghosts in antigen presenting cells. Journal of Biotechnology 83 57-66.

Heckels JE, Fletcher JN, Virji M 1989: The potential protective effect of immunization with outer membrane protein I from Neisseria gonorhoeae. Journal of General Microbiology 135 2269-2276. 
Jalava K, Hensel A, Szostak M, Resch S, Lubitz W 2002: Bacterial ghosts as vaccine candidates for veterinary applications. Journal of Control Release 85 17-25.

Katinger A, Szostak MP, Stadler M, Klein R, Huter V, Lubitz W 1999: Pigs aerogenously immunized with genetically inactivated (ghosts) of irradiated Actinobacillus pleuropneumoniae are protected against a homologous aerosol challenge despite differing in pulmonary cellular and antibody responses. Journal of Biotechnology $\mathbf{7 2}$ 247-256.

Kawai K, Liu Y, Ohnishi K, Oshima S 2004: A conserved 37 kDa outer membrane protein of Edwardsiella tarda is an effective vaccine candidate. Vaccine 22 3411-3418.

Kvitt K, Colorni A 2004: Strain variation and geographical endemism in Streptococcus iniae. Disease of Aquatic Organism 61 67-73.

Kwon SR, Nam YK, Kim SK, Kim DS, Kim KH 2005: Generation of Edwardsiella tarda ghosts by bacteriophage PhiX174 lysis gene E. Aquaculture 250 16-21.

Marchart J, Dropmann G, Lechleitner S, Schlapp T, Wanner G, Szostak MP 2003: Pasteurella multocida- and Pasteurella haemolyticaghosts: New vaccine candidates. Vaccine 21 3988-3997.

Panthel K, Jechlinger W, Matis A, Rohde M, Szostak M, Lubitz W 2002: Generation of Helicobacter pylori ghosts by PhiX protein E-mediated inactivation and their evaluation as vaccine candidates. Infection Immunology 71 109-116.

Park YK, Nho SW, Shin GW, Park SB, Jang HB, Cha IS, Ha MA, Kim YR, Dalvi RS, Kang BJ, Jung TS 2009: Antibiotic susceptibility and resistance of Streptococcus iniae and Streptococcus parauberis isolated from olive flounder (Paralichthys olivaceus). Veterinary Microbiology 136 76-81.

Scho"n P, Schrot G, Wanner G, Lubitz W, Witte A 1995: Two-stage model for integration of lysis protein E of bacteriophage PhiX174 into the cell envelope of Escherichia coli. FEMS Microbiology Review 17 207-212.

Shoemaker C, Klesius P 1997: Streptococcal disease problems and control: a review. In: Fitzsimmons K (Edn), Tilapia Aquaculture vol. 2 Northeast Regional Agricultural Engineering Service-106, Ithaca, NY, USA, pp. 671-680.

Szostak MP, Hensel A, Eko FO, Klein T, Mader H, Haselberger A 1996: Bacterial ghosts: non-living candidate vaccines. Journal of Biotechnology 4 161-70.

Witte A, Lubitz W 1989: Biochemical characterization of øX174-protein-E-mediated lysis of Escherichia coli. European Journal of Biochemistry 180 393-398.

Witte A, Schrot G, Scho“n P, Lubitz W 1997: Proline 21, a residue within the a-helical domain of $ø X 174$ lysis protein $\mathrm{E}$, is required for its function in Escherichia coli. Molecular Microbiology 26 337-346.

Witte A, Wanner G, Lubitz W 1992: Dynamics of PhiX174 protein E-mediated lysis of Escherichia coli. Archive Microbiology 157 381-388.

Yin Z, Lam TJ, Sin YM 1996: The role of specific antiserum of catfish, Clarias gariepinus, as a defence against Aeromonas hydrophila. Fish and Shellfish Immunology 6 57-69. 